Crime, Histoire \& Sociétés / Crime, History \& Societies

Vol. 21, $n^{\circ} 2$ | 2017

L'histoire de la criminalité et de la justice pénale : propositions de recherche pour le $21^{\mathrm{e}}$ siècle

\title{
Crime and Criminal Justice Research: Australia and its Region
}

Mark Finnane

\section{(2) OpenEdition \\ Journals}

Electronic version

URL: http://journals.openedition.org/chs/1872

DOI: $10.4000 /$ chs. 1872

ISSN: 1663-4837

\section{Publisher}

Librairie Droz

\section{Printed version}

Date of publication: 31 December 2017

Number of pages: 183-194

ISSN: $1422-0857$

\section{Electronic reference}

Mark Finnane, "Crime and Criminal Justice Research: Australia and its Region", Crime, Histoire \& Sociétés / Crime, History \& Societies [Online], Vol. 21, n² | 2017, Online since 19 July 2020, connection on 12 January 2021. URL: http://journals.openedition.org/chs/1872 ; DOI: https://doi.org/10.4000/ chs. 1872 


\title{
Crime and Criminal Justice Research: Australia and its Region
}

\author{
Mark Finnane
}

$\mathbf{R}$ esearch on crime and criminal justice history for Australia and its region Ris almost entirely restricted chronologically to the period since 1788 . That was the year when transported convicts sentenced in England first landed at their destination in Botany Bay.

The geo-temporal location of the area "Australia and its region" is one defined initially by the region's imperial and colonial histories ${ }^{1}$. The dominant imperial power was Britain, and its proxies, the British-populated settler colonies of Australia and New Zealand. Australia itself became an imperial power through its role in annexing part of its northern neighbour New Guinea after 1885. Other European imperial powers played a role in the region, especially the Dutch in the East Indies and extending to the western part of New Guinea, the French especially in New Caledonia which it used as a convict colony, the Germans, also in New Guinea, and the Portuguese in East Timor. The islands of the south-west Pacific were variously absorbed by these European powers during the late nineteenth-century imperial expansion. And briefly in the twentieth century they were also controlled by the Japanese imperial expansion into the south Pacific.

Recalling these macro-historical contexts is a reminder of the conditions under which crime occurred and criminal justice institutions developed. Importantly, these islands, occupied and transformed by the weight of imperial expansion in the nineteenth and twentieth centuries, were places already occupied by peoples, Melanesian, Polynesian, Australian Aboriginal, who possessed their own legal norms and institutions. The displacement of these indigenous traditions was troubled and troubling. Long term the recognition of these other ways of life invigorated more reflective discussion about law and culture and legal institutions, inspiring sometimes adventurous experimentation in responses to crime and violence. Contemporary interest in the mechanisms of restorative justice for example has had a particular salience in Australia and its region ${ }^{2}$. The point is that the story of crime and criminal justice histories in this region is one that is culturally diverse, and in which the influences shaping institutional responses to crime and violence have flowed two ways even during the age of imperial domination.

Although not a dominant tradition intellectually, the region is conceptualised as a geohistorical space in some compendious transnational histories like Denoon et al. (2000); Grattan (1963); Armitage and Bashford (2014).

2 The most striking example is represented in the work of John Braithwaite - whose capacious field of reference includes Japanese and Confucian cultural themes, Australian convict colonies and Australian colonial administration of Melanesian peoples in PNG. See Braithwaite (1989, 2001); Dinnen and Braithwaite (2009). 
In terms of intellectual engagement with crime and criminal justice the largest body of work in this region has been focussed on Australia, and the product of historians working in Australia. Major contributions however, disproportionately so, have come out of New Zealand and won international attention. Much less historical work, especially in recent decades, has been engaged with the neighbouring countries of the region, most of them Melanesian.

In the brief perspective offered below on the future of crime and criminal justice history research in this region I will attempt first of all to recount briefly the focus of existing work, not so much a historiography as a mapping of some of the areas that have received attention previously. Second, I will offer my own view of some research priorities for the immediate future. Last I will discuss the kind of approach to enabling future research on crime and criminal justice that is offered by the Prosecution Project, a research undertaking of which I am currently the director.

\section{THE STATE OF THE FIELD}

The writing of crime histories in Australia and its region has for the most part been coincident with the rise of social history and the post-colonial reconfiguration of the numerous polities of the region. The momentous clash of imperial power and settler colonialism with indigenous cultures has become a central concern of contemporary historiography. How far is this reflected in research on crime and criminal justice history? Or should we ask, how has this historiographical renewal dealt with crime and the criminal law? Are crime and the criminal law at the margins or near the centre of this clash?

In recent years it has been argued with great force that jurisdiction over crime, the basis on which criminal justice institutions have developed, is at the very centre of imperial power. In a striking demonstration of the power of comparative research Lisa Ford showed that criminal jurisdiction was at the very core of debates around the sovereignty of settler states in their dealings with indigenous peoples in early convict New South Wales as in (the still slave) state of Georgia ${ }^{3}$. When indigenous peoples committed crimes against each other, even more than when they committed crimes against, or were the victims of, settlers, the response of law and justice institutions became a critical test of sovereignty. The clarity of that study has broadened the scope of the study of criminal law and institutions in these societies, inviting us in effect to look back at earlier histories of the foundational years of imperial hegemony. So we might recall the particular force of Richard Hill's compendious study of the New Zealand police, its early decades shaped by the pervasive conflict between Maori and Pakeha, leading even to experimentation with a Maori constabulary, a history shaped by Hill's study of the policing continuum of coercion and consent ${ }^{4}$. A more obscure though no less impressive, account of the incremental development of the colonial state through its legal institutions is Peter Sack's study of the German imperial administration of New Guinea, a short-lived but nevertheless instructive experiment that highlights the challenges of attempting to govern "custom" through

Ford (2010).

4 Hill (1986). 
the formalities of European legal codes and institutions ${ }^{5}$. The irresolution of the conflict between custom (ever changing anyway under colonial and imperial rule) and the law of the newcomers remains a compelling story, though one deserving much more research attention ${ }^{6}$.

The largely nineteenth century colonisation of the region was contemporaneous with the development of modern policing. The varied colonial settings could however produce different institutional patterns. The weakness of local settler communities married with the autocratic style of colonial administration to drive the establishment of police forces that were centrally controlled. That remained the case into the twentieth century, ensuring that police forces were very large components of government, whatever the jurisdiction ${ }^{7}$. Policing indigenous peoples was more often the task of general than specialised police, the Queensland Native Police (1864c. 1900) a notorious long-lived exception ${ }^{8}$. The structures of policing, the styles of administration and resourcing, drew both from the British and Irish models. Being always an urban society, in spite of national mythologies, the demands of policing in Australia were well suited to the regular patrolling and bureaucratic recording that characterised the "beat", as ably documented by Dean Wilson's study of Melbourne?. Twentieth century policing has received limited attention, beyond that found in a few institutional histories, mainly for Victoria and Queensland ${ }^{10}$. An exception to this rule is the interest paid to the policing of dissent and public order, histories that demand also attention to the border shared with security and more recently counter-terrorist policing ${ }^{11}$.

Given the convict origins of Australian settlement it is scarcely surprising that the convict experiment has been a preoccupation. Early studies achieved a great deal through study of significant samples of the transported population, highlighting penal policy as a response (often crude and brutal) to a crisis of criminality in the UK and Ireland in the late eighteenth and early nineteenth century ${ }^{12}$. But since the 1980 s these have been increasingly revised by large scale projects that have highlighted what the convict population shared with the populations from which they derived ${ }^{13}$. And more recently the voluminous records of the transportation period have spawned major inquiries into the health and post-convict careers of the tens of thousands transported, inquiries that now extend beyond the convict experience into later prison populations, taking advantage of the legacy of biometric measurement of captured populations ${ }^{14}$. Another inflection of the convict experience is registered in the increasing attention to the experience of women under transportation - with respect both to their offending

Sack (2001).

Douglas and Finnane (2012).

Dunstall (1999); Finnane (1994); Kituai (1998).

J. Richards (2008); Owen (2016); Nettelbeck and Foster (2007).

Wilson (2006); Dukova (2016).

10 Haldane (1986); Johnston (1992).

11 Baker (2004); Finnane (2002); Horner (2014); Hocking (1993).

12 Shaw (1977); Robson (1994); Hughes (1988).

13 Nicholas (1988); Oxley (1996).

14 Maxwell-Stewart et al. (2012); Inwood et al. (2015). 
origins, their transportation experience and their post-arrival histories in the convict colonies ${ }^{15}$. The history of the places of secondary punishment, which spawned the inventive strategies of Alexander Maconochie, as well as of the convict labour system and its legal regulation, remain productive sites of research ${ }^{16}$. The New Caledonia penal colony was of much smaller scale and duration, its presence in the region nevertheless a reminder of the impact of transportation on the Pacific ${ }^{17}$.

The history of punishment after European settlement has been unevenly examined. The penitentiary was emerging during the critical years in which transportation populated the Australia colonies, and its elements shaped the penal landscape of postconvict Australia as it did New Zealand ${ }^{18}$. The prison all the same remains an understudied institution in contrast to policing, much of the recent research known to this author now lying in rarely consulted but invaluable doctoral theses. Other modes of punishment, especially capital punishment, have attracted a good deal of attention, flowing still from the political struggles over its use, abandoned in Australia after 1967, but still present in public discourse ${ }^{19}$. Valuable studies of its deployment have compared Australian uses of hanging and commutation with Canadian, examined the use of exemplary public hangings in "civilising" indigenous peoples and considered the longevity of Australian uses of capital punishment in responding to sexual violence ${ }^{20}$. Australia's history as a colonial power was the context for a particularly egregious use of hanging in "native administration" in Papua New Guinea in the 1920 s to $1940 \mathrm{~s}^{21}$.

Beyond the death penalty, however, specific historical studies of penality have generally only been pursued as an incident of more general studies of crime. Here also the record is very uneven. One of the earliest, Peter Grabosky's study of crime in Sydney was the product of his role in the international research project on crime in cities directed by Ted Robert Gurr in the early $1970 \mathrm{~s}^{22}$. No other Australian state or city has a comparable survey history. More detailed studies of Sydney have dealt with the convict era and its aftermath, notably the focus of work by Byrne and Sturma ${ }^{23}$. A wide-ranging criminological study of crime in Australian society in the twentieth century was conducted in the 1980s by researchers at the Australian Institute of Criminology, its data drawn primarily from the very uneven official statistics of the various Australian states ${ }^{24}$.

Australian histories of crime in recent decades have commonly engaged with issues of gender and race. Many of the historians responsible for these histories have highlighted in their work the linkage to contemporary questions of justice and rights.

\footnotetext{
Oxley (1996); Damousi (1997); Smith (2008); Harrison (2016).

Maxwell-Stewart (2008); Harman (2012).

Forster (1996); Toth (2006).

18 Pratt (1992); Finnane (1997); Kerr (1988).

19 B. Jones (1968); M. Richards (2002); Adams (2009).

20 Strange (1996); Kaladelfos (2012b); McGuire (1998); Anderson (2015).

21 Nelson (1978).

22 Grabosky (1977).

23 Byrne (1993); Sturma (1983).

24 Mukherjee (1981).
} 
The role of women as both perpetrators and victims of crime provided Judith Allen in the 1980s with a reason to question the truths of official statistics and contemporary criminology ${ }^{25}$. Crimes of sexual assault have also received a good deal of attention, with Bavin-Mizzi adopting the generally rare approach of comparative jurisdictional study in her study of a variety of sexual offences in the late nineteenth and early twentieth centuries ${ }^{26}$. In research published mainly in journal articles, a number of researchers have taken up the challenge of examining the intersection of race and gender in studies of sexual assault and the social anxieties it may breed ${ }^{27}$. Studies of prostitution have highlighted as elsewhere the critical role of policing and law, bringing attention also to the histories of vagrancy law ${ }^{28}$. Although rarely used, a 1926 ordinance targeting the protection of white women was a historical expression of colonialism that Inglis used tellingly to explore the social context of crime and policy in colonial Papua ${ }^{29}$. Studies of sexual crimes have continued to attract new researchers, recognising the potential of the twentieth century, notably in work on the prosecution and sentencing of rape in 1950s New South Wales, and a study of the policing and prosecution of homosexual offences in war-time Queensland ${ }^{30}$.

There are other examples of very particular local histories of crime that are not so closely tied to issues of gender or race. Bushranging, the Australian colonial equivalent of highway robbery by groups of men on horses, is a striking example. Its connection to the story of the iconic Australian outlaw, Ned Kelly, helped spawn a large industry of popular as well as scholarly literature. Hobsbawm's studies of social banditry were influential in revisionist histories contextualising bushranging, but much interest has also arisen from the nature of colonial responses, whether in shaping the emergence of policing or in the uses of law with exceptional powers to police, reverse onus of proof and harsh sentencing ${ }^{31}$. Urban policing of crime has been highlighted in work as various as the uses of space by young people in Sleight's inventive study of late nineteenth century Melbourne, and in McCoy's politically charged twentieth-century history of organised crime in the major centres of Sydney and Melbourne ${ }^{32}$. There is no Australian equivalent of Fairbairn's study of anomie in New Zealand, a sociological big picture that remains vulnerable in its selective study of crime data ${ }^{33}$.

What this brief survey points to is the patchwork state of crime and criminal justice histories in Australia and its region. Beyond Woods' major study of nineteenth century criminal law in New South Wales, the study of the criminal law itself remains in its infancy ${ }^{34}$. Studies of major crime categories including homicide and most

Allen (1990).

26 Bavin-Mizzi (1995).

27 Kaladelfos (2012a); Harris (1982); Evans (1982).

28 Frances (2007); Davies (1994).

29 Inglis (1974).

30 Featherstone and Kaladelfos (2016); Smaal (2015).

31 McQuilton (1979); West (2009); Hirst (1988); I. Jones (1995); Seal (1996); Bennett (2009).

32 Sleight (2013); A.W. McCoy (1980); A. McCoy (1986).

33 Fairburn (1989); Dunstall (2004).

34 Woods (2002). See also, for South Australia, Taylor (2005). 
kinds of property offence are rare, an exception being the criminal law's response to Aboriginal homicide ${ }^{35}$. And research capacity in my view is on the decline in respect of the region - the decline of Pacific history as a major area of focus in the universities in Australia and New Zealand is notable and will be a significant restraint on any future research agenda in the region. Another structural restraint is the collapse of the academic book market - although monographs are still being published the range of work is limited and the best work often still languishes in university thesis libraries. Against this background I offer in the following pages some comments on priority areas for attention by future historians, before considering a new methodology and resource that might help advance the field.

\section{FUTURE AGENDAS}

Enough has been said in the above mapping to highlight the strengths as well as gaps and weaknesses of crime and criminal justice history research in Australia and its region. So what might the future hold?

Thinking at the regional level we might consider a number of possible areas that could highlight the reality of the geo-historical space. Some of these spring from emergent trends in historical work generally. One might concern the transfer of ideas and policies: how has the historical specificity of the region shaped contemporary characteristics of criminal justice institutions? What have been the legacies of colonial and imperial histories given the double layers of imperial control, first of the European powers (especially Britain, France, Germany) then of the local hegemons (Australia and New Zealand)?

Another might investigate the criminalisation of regional mobility - how were population movements governed historically and what was the role of criminal law and policing in controlling such movement? These are questions that have significance within and between jurisdictions, whether in the era of convict colonies (including Australia and New Caledonia), or in the age of labour migration involved with the sugar plantation economy of the late nineteenth century (tying Queensland to a number of Pacific Islands), or in twentieth century migration policy (e.g. the White Australia Policy and its New Zealand equivalent), or very recently in the revitalised neo-colonial relations that have enabled Australian governments to "manage the border" by shipping "illegal maritime arrivals" to destinations in the independent Pacific states of Papua New Guinea and Nauru.

Other priorities will share much with the agendas that continue to preoccupy the field generally. The history of violence demands attention for its continuing political salience and policy implications - domestic violence, the violence of intimates, will receive increasing attention as the field moves beyond the focus on inter-racial and frontier histories. But areas of crime that have received limited attention to date may benefit from the increased accessibility of new sources, as discussed below - the history of property crime, both street level and "white collar" is an area that has received relatively little attention, especially relative to major part in the criminal justice process. Such histories will benefit by moving beyond a social history preoccupation with experience to encompass also an inquiry into the political economy of criminal

35 Auty (2005); Douglas and Finnane (2012); Egan (1996); Nettelbeck and Foster (2007). 
behaviour, its intersections with fluctuations in economic fortune and opportunity. The region's experience of boom and bust economics, especially associated with extractive industries, make this a priority for future attention.

For all parts of the region, the plurality of cultures will demand continuing investigation - whether into the responses of sovereign law to the challenges of other legal systems within and between the bounds of territorial states; or inquiring into the relations between formal and informal systems of law, policing, punishment, stigmatization, and social integration.

From the vantage point of scholars working now in the twenty-first century we might also expect that future scholarship will take up the challenge of working on the twentieth century. The impact of wars, global and local, together with the multiplication of government agencies concerned with problems of security and safety, offer particularly productive fields of future inquiry into crime, its contexts and consequences.

\section{NEW DATA AND NEW METHODS}

In addressing these future questions research will increasingly by shaped by the accessibility of historical archives in digital form. Although the coverage of digitisation remains low for the kinds of materials required for many of the questions raised above, the potential is already identified, the age of "digital archaeology" is upon us ${ }^{36}$. In Australia and its region, researchers are now able to access almost the entire corpus of historical newspapers in the nineteenth and first half of twentieth centuries, or the historical libraries of statutes and legal cases for major Australian and New Zealand jurisdictions for much of the nineteenth and twentieth centuries ${ }^{37}$.

In this respect the possibilities and challenges of accessing large amounts of data demand attention. A current Australian project, the Prosecution Project seeks to provide that increased access on the basis of an archival retrieval that is structured and open ${ }^{38}$. As the method applied by the Prosecution Project is one that may be extended to other kinds of jurisdictions (indeed its very infrastructure may well be accessed for such purposes), I outline here briefly the steps in the data retrieval and storage process that produces new datasets that future researchers will be able to access with their own questions and agendas.

First, the project focus is on the process of criminal prosecution ending in a trial and possible conviction and sentence. Our access to this process of prosecution is organised through the digitisation of the court registers of each criminal jurisdiction (in Australia this means principally the six States, which were colonies before 1901). No two jurisdictions are the same in their record-keeping but typically such registers will include details of name, offence, place of trial, verdict and (if convicted) sentence, but may extend to name of judge, date of original committal (at magistrate's court),

\footnotetext{
36 Godfrey (2016, p.45); Robertson (2016).

37 For Australian newspapers, http://trove.nla.gov.au/; for New Zealand, https://paperspast.natlib.govt.nz/ newspapers. For legal history materials for both countries http://www.austlii.edu.au/au/special/legalhistory/.

38 Mark Finnane, Andy Kaladelfos, Alana Piper,Yorick Smaal, Robyn Blewer and Lisa Durnian et al., The Prosecution Project Database https://prosecutionproject.griffith.edu.au/prosecutions (version 1, 17 July 2016). For a more detailed outline of the project see Finnane and Piper (2016).
} 
identity of co-accused, names of witnesses, prosecutors, defence lawyers and even the names of those posting bail. Importantly, by including the names of those acquitted as well as convicted, the scope of the record expands the sample of those caught up in the criminal justice process beyond the population ending in prison.

Accessing these records has proved a challenge in some jurisdictions. Typically the originals are held in public record offices, though some are still retained in the courts themselves. Some have been microfilmed some decades ago, and have been readily converted to digital files; others have to be digitally photographed anew. More importantly the process of digitisation is no mere technical matter. The manuscript records must be manually transcribed. This has been achieved in part by the efforts of a research team funded by the Australian Research Council but also by public volunteers recruited through the project website and other means, including the networks of genealogy and local history societies.

But most importantly the project has sought to establish a process that will create as permanent a record as possible, and one whose information may be readily accessed by a wide variety of interested parties. The appeal of the project to volunteers has been the public good as well as private interest associated with improved genealogical information resources. The value of the project to researchers in the longer term is a massive increase in accessible data. The transcription of the records is enabled by a web portal through which the data is entered in the structured format of a relational database. The individual records may be enriched at a later date by a variety of other information sources - including other public archival records of police, prosecution and prison agencies, or the immense records of newspaper reporting of crimes and trials.

The Prosecution Project data extend well into the twentieth century. Indeed the research priority that I have suggested earlier (moving into last century, now that we are in the twenty-first!) is one that enlivens the ambition of this project to provide an insight into transitions in the criminal trial and criminal justice in the more recent past. The project infrastructure however, sensitive to both a variety of data sources and emerging research questions, offers the possibility of extension beyond its particular institutional location. What such a project can never replace is the lost record, but where records have been preserved and have a consistency that makes possible their systematic reconstruction, then we have the possibility of extending jurisdictional reach and expanding comparative possibilities. I like to imagine that the future agenda of criminal justice history in this part of the world will expand our understanding of the region to advance beyond the national boundaries that too often constrain our interest and attention.

Mark Finnane Griffith Criminology Institute Griffith University Brisbane, Australia m.finnane@griffith.edu.au 


\section{BIBLIOGRAPHY}

Adams, S. (2009) The Unforgiving Rope: Murder and Hanging on Australia's Western Frontier, Crawley: W.A, UWA Publishing.

Allen, J. (1990) Sex \& Secrets: Crimes Involving Australian Women since 1880, Melbourne: Oxford University Press.

Anderson, S. (2015) Punishment as Pacification: The Role of Indigenous Executions on the South Australian Frontier, 1836-1862, Aboriginal History, 39, p.3-26.

Armitage, D. and Bashford, A. (2014) Pacific Histories: Ocean, Land, People, London: Palgrave.

Auty, K. (2005) Black Glass: Western Australian Courts of Native Affairs 1936-54, Fremantle: W.A, Fremantle Arts Centre Press.

Baker, D. (2004) Batons and Blockades: Policing Industrial Disputes in Australasia, Melbourne: Circa.

Bavin-Mizzi, J. (1995) Ravished: Sexual Violence in Victorian Australia, Sydney: University of New South Wales Press.

Bennett, J.M. (2009) Sir Alfred Stephen: Third Chief Justice of New South Wales 1844-1873. Lives of the Australian Chief Justices, Annandale: N.S.W, Federation Press.

Braithwaite, J. (1989) Crime, Shame, and Reintegration, Cambridge, Cambridge University Press.

Braithwaite, J. (2001) Crime in a Convict Republic, Modern Law Review, 64, p.11-50.

Byrne, P. (1993) Criminal Law and Colonial Subject: New South Wales, 1810-1830. Melbourne: Cambridge University Press.

Damousi, J. (1997) Depraved and Disorderly: Female Convicts, Sexuality and Gender in Colonial Australia. Cambridge: Cambridge University Press.

Davies, S. (1994) Ragged, Dirty... infamous and Obscene: the Vagrant in Late-NineteenthCentury Melbourne, in Philips, D. and Davies, S. (Eds.), A Nation of Rogues?: Crime, Law and Punishment in Colonial Australia, Carlton, Vic.: Melbourne University Press, p.141-66.

Denoon, D., Mein Smith, P. and Wyndham, M. (2000) A History of Australia, New Zealand, and the Pacific, Oxford: Blackwell.

Dinnen, S. and Braithwaite, J. (2009) Reinventing Policing through the Prism of the Colonial Kiap, Policing and Society, 19, 2, p.161-73.

Douglas, H. and Finnane, M. (2012) Indigenous Crime and Settler Law: White Sovereignty after Empire, London: Palgrave Macmillan.

Dukova, A. (2016) A History of the Dublin Metropolitan Police and Its Colonial Legacy, London: Palgrave Macmillan.

Dunstall, G. (1999) A Policeman's Paradise?: Policing a Stable Society, 1918-1945, Palmerston North: N.Z, Dunmore Press in association with the Historical Branch, Dept. of Internal Affairs.

Dunstall, G. (2004) Frontier And/or Cultural Fragment? Interpretations of Violence in Colonial New Zealand, Social History, 29, 1, p.59-83.

Egan, T. (1996) Justice All Their Own: The Caledon Bay and Woodah Island Killings 19321933, Melbourne: Melbourne University Press.

Evans, R. (1982) Don't You Remember Black Alice, Sam Holt? Aboriginal Women in Queensland History, Hecate, 8, 2, p.7-21. 
Fairburn, M. (1989) The Ideal Society and Its Enemies: The Foundations of Modern New Zealand Society, 1850-1900, Auckland: Auckland University Press.

Featherstone, L. and Kaladelfos, A. (2016) Sex Crimes in the Fifties, Carlton, Vic: Melbourne University Publishing.

Finnane, M. (1994) Police and Government: Histories of Policing in Australia, Melbourne: Oxford University Press.

Finnane, M. (1997) Punishment in Australian Society, Melbourne: Oxford University Press.

Finnane, M. (2002) When Police Unionise: The Politics of Law and Order in Australia, Sydney: Sydney Institute of Criminology.

Finnane, M. and Piper, A. (2016) The Prosecution Project: Understanding the Changing Criminal Trial Through Digital Tools, Law and History Review, 34, 4, p.873-91.

Ford, L. (2010) Settler Sovereignty: Jurisdiction and Indigenous People in America and Australia 1788-1836, Cambridge: Mass, Harvard University Press.

Forster, C. (2007) France and Botany Bay: The Lure of a Penal Colony, Carlton South, Victoria: Melbourne University Press.

Frances, R. (2007) Selling Sex: A Hidden History of Prostitution, Sydney, NSW: University of New South Wales Press.

Godfrey, B. (2016) The Crime Historian's Modus Operandi, in Knepper, P. and Johansen, A. (Eds.), The Oxford Handbook of the History of Crime and Criminal Justice, New York: Oxford University Press.

Grabosky, P.N. (1977) Sydney in Ferment: Crime, Dissent and Official Reaction 1788 to 1973, Canberra: Australian National University Press.

Grattan, C. (1963) The Southwest Pacific since 1900, a Modern History; Australia, New Zealand, the Islands, Antarctica, Ann Arbor: University of Michigan Press.

Haldane, R. (1986) The People's Force: A History of the Victoria Police, Carlton, Vic.: Melbourne University Press.

Harman, K. (2012) Aboriginal Convicts: Australian, Khoisan, and Maori Exiles, Sydney: UNSW Press.

Harris, C. (1982) The "terror of the Law" as Applied to Black Rapists in Colonial Queensland, Hecate, 8, 2, p.22-48.

Harrison, J. (2016) Shackled: Female Convicts at Moreton Bay 1826-1839. Collins Street East, VIC: Anchor Books Australia.

Hill, R. (1986) Policing the Colonial Frontier: The Theory and Practice of Coercive Social and Racial Control in New Zealand, 1767-1867, History of Policing in New Zealand, 1, Wellington, N.Z.: V.R. Ward.

Hirst, J. (1988) The Strange Birth of a Colonial Democracy: New South Wales 1848-1884, Sydney: Allen \& Unwin.

Hocking, J. (1993) Beyond Terrorism: The Development of the Australian Security State. St Leonards, N.S.W: Allen \& Unwin.

Horner, D. (2014) The Spy Catchers. Volume I: The Official History of ASIO, 1949-1963. Crows Nest, NSW: Allen \& Unwin.

Hughes, R. (1988) The Fatal Shore: A History of the Transportation of Convicts to Australia 1787-1868, London: Pan Books. 
Inglis, A. (1974) Not a White Woman Safe: Sexual Anxiety and Politics in Port Moresby, 19201934, Canberra: Australian National University Press.

Inwood, K., Oxley, L. and Roberts, E. (2015) Physical Growth and Ethnic Inequality in New Zealand Prisons, 1840-1975, The History of the Family, 20, 2, p.249-69.

Johnston, W. (1992) The Long Blue Line: A History of the Queensland Police, Brisbane: Boolarong. Jones, B. (1968) The Penalty Is Death: Capital Punishment in the Twentieth Century: Retentionist and Abolitionist Arguments with Special Reference to Australia. Melbourne: Sun Books in association with the Anti-Hanging Council of Victoria.

Jones, I. (1995) Ned Kelly: A Short Life, Melbourne: Lothian Books.

Kaladelfos, A. (2012a) The "Condemned Criminals": Sexual Violence, Race, and Manliness in Colonial Australia, Women's History Review, 21, 5, p.697-714.

Kaladelfos, A. (2012b) The Politics of Punishment: Rape and the Death Penalty in Colonial Australia, 1841-1901, History Australia, 9, 1, p.155-75.

Kerr, J. (1988) Out of Sight, Out of Mind. (Australia's Places of Confinement, 1788-1988), Sydney: S.H. Ervin Gallery, National Trust of Australia (NSW).

Kituai, A. (1998) My Gun, My Brother: The World of the Papua New Guinea Colonial Police, 1920-1960, Pacific Islands Monograph Series; no. 15, Honolulu: University of Hawaii Press.

Maxwell-Stewart, H. (2008) Closing Hell's Gates: The Death of a Convict Station, Crows Nest, N.S.W.: Allen \& Unwin.

Maxwell-Stewart, H., Cracknell, M. and Inwood, K. (2012) Height, Crime and Colonial History, America, 55, 2, p.416.

McCoy, A. (1986) Two Cities and Their Syndicates: A Comparative Urban History of Organised Crime, in Davidson, J. (Ed.), The Sydney-Melbourne Book, Sydney: Allen \& Unwin, p.97-118.

McCoy, A. (1980) Drug Traffic: Narcotics and Organized Crime in Australia, Sydney: Harper \& Row.

McGuire, J. (1998) Judicial Violence and the "Civilizing Process": Race and the Transition from Public to Private Executions in Colonial Australia, Australian Historical Studies, 29, 111, p.187.

McQuilton, J. (1979) The Kelly Outbreak, 1878-1880 : The Geographical Dimension of Social Banditry, Carlton, Vic.: Melbourne University Press.

Mukherjee, S. (1981) Crime Trends in Twentieth-Century Australia, Sydney, Boston: Australian Institute of Criminology in association with Allen \& Unwin.

Nelson, H. (1978) The Swinging Index: Capital Punishment and British and Australian Administrations in Papua and New Guinea, 1888-1945, Journal of Pacific History, XIII, 3, p.130-53.

Nettelbeck, A., and Foster, R. (2007) In the Name of the Law: William Willshire and the Policing of the Australian Frontier. Kent Town, S. Aust.: Wakefield Press.

Nicholas, S. (Ed.) (1988) Convict Workers: Reinterpreting Australia's Past, Cambridge: Cambridge University Press.

Owen, C. (2016) Every Mother's Son Is Guilty: Policing the Kimberley Frontier of Western Australia 1882 - 1905. Crawley, Western Australia: UWA Publishing.

Oxley, D. (1996) Convict Maids: The Forced Migration of Women to Australia, Cambridge: Cambridge University Press. 
Pratt, J. (1992) Punishment in a Perfect Society: The New Zealand Penal System 1840-1939. Wellington: Victoria University Press.

Richards, J. (2008) The Secret War: A True History of Queensland's Native Police/Jonathan Richards, St Lucia, Qld: University of Queensland Press.

Richards, M. (2002) The Hanged Man: The Life \& Death of Ronald Ryan, Carlton North, Vic.: Scribe.

Robertson, S. (2016) Searching for Anglo-American Digital Legal History, Law and History Review, 34, 4, p.1047-69.

Robson, L. (1994) The Convict Settlers of Australia, Carlton, Vic.: Melbourne University Press.

Sack, P. (2001) Phantom History, the Rule of Law and the Colonial State: The Case of German New Guinea / Peter Sack, Canberra: Division of Pacific and Asian History, Australian National University.

Seal, G. (1996) The Outlaw Legend: A Cultural Tradition in Britain, America and Australia, Cambridge; Melbourne: Cambridge University Press.

Shaw, A. (1977) Convicts and the Colonies: A Study of Penal Transportation from Great Britain and Ireland to Australia and Other Parts of the British Empire, Carlton, Vic.: Melbourne University Press.

Sleight, S. (2013) Young People and the Shaping of Public Space in Melbourne, 1870-1914, Farnham: Ashgate.

Smaal, Y. (2015) Sex, Soldiers and the South Pacific, 1939-45: Queer Identities in Australia in the Second World War, Basingstoke, Hampshire: Palgrave Macmillan.

Smith, B. (2008) Australia's Birthstain: The Startling Legacy of the Convict Era, Crows Nest, N.S.W: Allen \& Unwin.

Strange, C. (1996) Discretionary Justice: Political Culture and the Death Penalty in New South Wales and Ontario, 1890-1920, in Strange, C. (Ed.) Qualities of Mercy: Justice, Punishment, and Discretion, Vancouver, B.C.: UBC Press.

Sturma, M. (1983) Vice in a Vicious Society: Crime and Convicts in Mid-Nineteenth-Century New South Wales, St. Lucia, Qld; New York: University of Queensland Press.

Taylor, G. (2005) A Great and Glorious Reformation: Six Early South Australian Legal Innovations, Kent Town, S. Aust.: Wakefield Press.

Toth, S. (2006) Beyond Papillon: The French Overseas Penal Colonies, 1854-1952, Lincoln: University of Nebraska Press.

West, S. (2009) Bushranging and the Policing of Rural Banditry in New South Wales, 18601880, Kew, Vic.: Australian Scholarly Publishing.

Wilson, D. (2006) The Beat: Policing a Victorian City. Beaconsfield, Vic.: Melbourne Publishing Group.

Woods, G. (2002) A History of Criminal Law in New South Wales: The Colonial Period, 17881900, Annandale NSW: Federation Press. 